\title{
Krukenberg Tumor of Breast Origin
}

\author{
Enver Ilhan ${ }^{a}$ Ibrahim Gulhan ${ }^{b}$ Nazif Erkan ${ }^{a} \quad$ Cem Buyuktosun ${ }^{c} \quad$ Sevil Sayhan $^{d}$ \\ a Department of General Surgery, \\ ${ }^{b}$ Department of Gynecology and Obstetrics, Izmir Training and Research Hospital, \\ ${ }^{c}$ Department of Gynecology and Obstetrics, \\ ${ }^{\mathrm{d}}$ Department of Pathology, Ege Maternity Hospital, Izmir, Turkey
}

\section{Key Words}

Krukenberg tumor - Breast cancer

\section{Summary}

Background: The term Krukenberg tumor refers to metastatic disease of the ovary, especially those metastases containing mucin-secreting signet ring cells. Krukenberg tumor of breast origin is not a frequent condition. Case Report: A 49-year-old postmenopausal woman was admitted with pains in her breast, and masses in both breasts were biopsied. Pathology showed invasive ductal cancer with mucin-secreting signet ring cells. X-rays of the spinal column confirmed metastasis to the thoracic vertebrae, and the patient was found to have stage 4 breast cancer. Treatment consisted of chemotherapy, palliative radiotherapy and adjuvant hormone therapy with tamoxifen. The patient showed good response to treatment and was stable for 2 years. She was admitted to our clinic complaining of pelvic pain. Local recurrence, multicentric bone metastases with a right adnexal mass and ascites were detected. We performed total abdominal hysterectomy, bilateral salpingooophorectomy and appendectomy. The pathological diagnosis of the tumor revealed metastasis of signet ring cell breast cancer to the right ovary. The patient was treated with letrozole $2.5 \mathrm{mg} /$ day and zoledronic acid $4 \mathrm{mg} / \mathrm{day}$ and is alive 5 months after surgery. Conclusion: Even though complete response to chemoradiotherapy in advanced breast cancer is possible, Krukenberg tumors of breast origin may be seen in the followup period.
Schlüsselwörter

Krukenberg-Tumor · Brustkrebs

\section{Zusammenfassung}

Hintergrund: Der Begriff Krukenberg-Tumor bezieht sich auf Eierstocksmetastasen, insbesondere solche, die schleimproduzierende Siegelringzellen enthalten. Von der Brust stammende Krukenberg-Tumore sind selten. Fallbericht: Eine 49-jährige postmenopausale Frau wurde mit Schmerzen in der Brust eingewiesen, und in beiden Brüsten wurden Geschwülste gefunden, von denen Biopsien entnommen wurden. Die pathologische Untersuchung ergab ein invasives duktales Karzinom mit schleimproduzierenden Siegelringzellen. Röntgenaufnahmen der Wirbelsäule zeigten Metastasen in den Brustwirbeln, und die Patientin hatte Brustkrebs im Stadium 4. Die Behandlung bestand aus Chemotherapie, palliativer Radiotherapie und adjuvanter Hormontherapie mit Tamoxifen. Die Patientin sprach gut auf die Behandlung an und ihr Zustand war 2 Jahre lang stabil. In unsere Klinik wurde sie mit Schmerzen im Beckenbereich eingewiesen. Die Untersuchung ergab ein lokales Rezidiv, multizentrische Knochenmetastasen und einen Adnextumor am rechten Eierstock sowie Aszites. Eine totale abdominale Hysterektomie, eine bilaterale SalpingoOophorektomie sowie eine Appendektomie wurden durchgeführt. Der pathologische Befund ergab, dass es sich bei dem Tumor im rechten Eierstock um Metastasen eines siegelringzelligen Mammakarzinoms handelte. Die Patientin wurde mit Letrozol $2.5 \mathrm{mg} / \mathrm{d}$ und Zoledronsäure $4 \mathrm{mg} / \mathrm{d}$ behandelt und ist 5 Monate nach ihrer Operation noch immer am Leben. Schlussfolgerung: Obwohl ein komplettes Ansprechen auf die Chemoradiotherapie bei fortgeschrittenem Brustkrebs möglich ist, könnte es während der Follow-up-Periode zum Auftreten von Krukenberg-Tumoren kommen, welche ihren Ursprung in der Brust haben.

\begin{tabular}{ll}
\hline KARGER & $\odot$ 2007 S. Karger GmbH, Freiburg \\
Fax +49 76145207 14 & Accessible online at: \\
$\begin{array}{l}\text { E-mail Information@Karger.de } \\
\text { www.karger.com }\end{array}$ & www.karger.com/brc
\end{tabular}




\section{Introduction}

Breast cancer is the most common site-specific cancer and is the leading cause of death from cancer in women [1]. Gynecological tumors such as ovarian, uterine and cervical cancers, are also sex-specific malignancies that pose a significant risk for women. Metastatic ovarian tumors are thought to account for approximately $10-30 \%$ of malignant ovarian tumors. In the case of breast cancer, microscopic ovarian metastases are occasionally diagnosed in connection with prophylactic oophorectomy. The term Krukenberg tumor refers to metastatic disease of the ovary, especially those metastases containing mucin-secreting signet ring cells. Most of these tumors arise in the gastrointestinal tract although the term Krukenberg tumor has also been used to describe metastatic disease to the ovary from other sites such as the breast [2,3]. In this report, we present the case of a 49-year-old woman with a Krukenberg tumor of breast origin.

\section{Case Report}

A 49-year-old postmenopausal woman was admitted to our clinic due to breast pain in December 2003. Breast examination, breast ultrasonography and mammography confirmed bilateral breast masses. The masses were located symmetrically in the upper quadrant of the breast, and the size of the masses was $3 \mathrm{~cm}$ in the right and $4 \mathrm{~cm}$ in the left breast. Bilateral excisional breast biopsies were performed, and histopathology showed invasive ductal cancer with mucin-secreting signet ring cells. The immunohistochemical assessment of the biopsies revealed estrogen receptor $(+++)$, progesterone receptor $(++)$ and erb-2/neu $(+++$, strong membranous staining) for the right and estrogen receptor $(+++)$, progesterone receptor $(+)$ and erb-2/neu (++, membranous staining) for the left breast mass. Endoscopy of the gastrointestinal tract, pelvic and abdominal ultrasonography and bimanual pelvic examination were all normal. However, X-rays of the spinal column confirmed metastasis to the thoracic vertebrae.

The patient was shown to have stage 4 breast cancer and was treated with chemotherapy that consisted of 6 cycles of fluorouracil, epirubicin and cy clophosphamide and 1 cycle of palliative radiotherapy to the bone metastases. After completion of this therapy, tamoxifen as adjuvant hormonal treatment was planned for the following 5 years. The patient was then put on tamoxifen $(20 \mathrm{mg} /$ day) hormone therapy between 2 clinical observations. She had a good response to the treatment and did well for 2 years. There was no sign of breast or systemic disease. Mammography, breast ultrasonography, breast examination, pelvic, abdominal ultrasonography, and tumor markers were all within the normal range during this period.

After an uncontrolled period of 8 months, in April 2006, the patient was admitted to our clinic complaining of pelvic pain. Pelvic examination and pelvic ultrasonography revealed a right adnexal mass and ascites. The uterus and left ovary were normal, and there were no signs of gastrointestinal disease. Endoscopy of the gastrointestinal tract and endoscopic biopsies showed no malignant disease. Breast examination, ultrasonography and mammography findings showed bilateral multicentric recurrent masses. Tumor markers were elevated as follows: CA-125 $264 \mathrm{U} / \mathrm{ml}$, CA15-3 > $300 \mathrm{U} / \mathrm{ml}$, CEA $438 \mathrm{ng} / \mathrm{ml}$. Furthermore, the vertebrae showed multiple bone metastases.

After the above-mentioned findings, in April 2006, we performed a total abdominal hysterectomy, bilateral salpingo-oophorectomy and appendectomy. At the time of surgery, exploration of the abdomen and pelvis

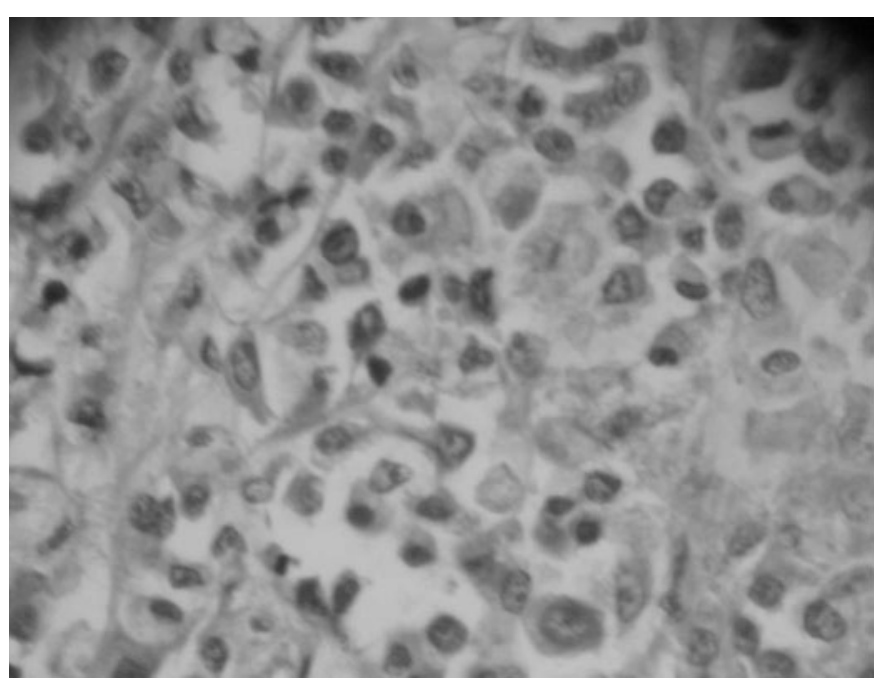

Fig. 1. Histopathologic assessment of Krukenberg tumor: Single mucinfilled signet ring cells forming tiny glands, lying within a reactive cellular stroma (H \& E).

showed a large amount of ascites and an $18 \times 20$-cm semisolid, septated, unruptured tumor arising from the right ovary. Pathology revealed metastasis of signet ring cell breast cancer to the right ovary (fig. 1). There was no malignancy in the uterus, left ovary, omentum or appendix, but signet ring cells were also seen in the ascites fluid. After the operation, the patient recovered well. She was treated with letrozole $2.5 \mathrm{mg} /$ day as adjuvant hormone therapy and zoledronic acid $4 \mathrm{mg} /$ day for 5 months. She is alive with recurrent breast disease 5 months after surgery.

\section{Discussion}

Breast cancer is well known to be associated with metastases that become clinically evident a long time after mastectomy. The ovaries are the frequent target of metastasis during the course of breast cancer. In the literature, the reported incidence of metastasis to the ovaries and breast cancer differs. Lumb and Mackenzie [4] reported that $29.4 \%$ of breast cancer patients who underwent prophylactic oophorectomy had ovarian metastases. In the study of Webb et al. [5], this incidence was reported to be $31 \%$. However, Horie et al. [6] reported that breast tumors as the primary tumor site accounted for $13 \%$ of ovarian metastases.

The classic pattern of Krukenberg tumor, which is characterized by single mucin-filled signet ring cells or small groups of them often forming tiny glands and lying within a reactive cellular stroma, is seen in the ovaries. In young patients, Krukenberg tumors occur more often than other types of metastatic ovarian tumors. According to Kiyokowa et al. [3], over $40 \%$ of patients are under 40 years of age, the average age being 45 years. Although, ovarian metastasis is frequently seen in connection with breast cancer, the Krukenberg tumor of breast origin is a rare condition. In a study by Gagnon et al. [7], 64 
(38\%) of 165 cases of ovarian metastasis were found to stem from breast cancer, and none had features of a Krukenberg tumor. In a review by Yada-Hashimoto et al. [8], 64 cases of ovarian metastasis were evaluated. In this study, 11 cases of Krukenberg tumor were found of which 8 originated in the stomach and none originated in breast. In a comprehensive review of the literature, $6 \%$ of 530 Krukenberg tumors were of breast origin [3].

Le Bouedec et al. [9] reported that the interval between mastectomy for breast cancer and the development of a Krukenberg tumor ranged from 1.5 to 12 years. The median interval between the diagnosis of breast cancer and ovarian metastasis in the Gagnon study [7] was 11.5 months, and the median survival after the diagnosis of ovarian metastases was 16 months. In our patient, the interval between the diagnosis of breast cancer and the ovarian metastasis was 26 months.

Metastatic ovarian lesions are usually bilateral with a non-cystic pattern and are more likely to be from primary infiltrating lobular cancer of the breast [10]. In a retrospective study by Le Bouedec et al. [9] assessing the characteristics of mucocel- lular ovarian cancer secondary to breast cancer, 10 cases of ovarian cancer of mucocellular origin were evaluated. In 7 out of 10 cases, the primary breast cancer was an invasive lobular carcinoma. In contrast, our patient's disease was characterized by large, unilateral lesions from invasive ductal cancer of the breast.

The development of ovarian metastasis during the course of any type of cancer is a negative prognostic factor (with regard to the presence or absence of peritoneal dissemination). Most patients die within 1 year of diagnosis of ovarian metastasis. It was reported that the 5-year survival rate after resection of metastatic ovarian tumors from gynecological and nongynecological organs were 47 and $19 \%$, respectively, which is a significant difference [8]. In the study by Webb et al. [5], the overall survival rate of patients with metastatic ovarian tumors was $12 \%$ (stomach: $5.4 \%$, breasts: $8.5 \%$, gynecological organs $34 \%$ ). In conclusion, even though a complete response to chemoradiotherapy can be gained in advanced breast cancer, Krukenberg tumors of breast origin may be seen during the follow-up period.

\section{References}

1 Blond KI, Beenker WS, Copeland EM: The breast; in Brunicardi FC, Andersan DK (eds): Schwartz's Principals of Surgery (ed 8). New York, Mc GrawHill, 2005, pp 453-500.

2 Holtz F, Hart WR: Krukenberg tumors of the ovary: a clinicopathologic analysis of 27 cases. Cancer 1982;50:2438-47.

3 Kiyokawa T, Young RH, Scully RE: Krukenberg tumors of the ovary: a clinicopathologic analysis of 120 cases with emphasis on their variable pathologic manifestations. Am J Surg Pathol 2006;30: 277-99
4 Lumb G, Mackenzie DH: The incidence of metastases in adrenal glands and ovaries removed for carcinoma of the breast. Cancer 1959;12:251-6.

5 Web MJ, Decker DG, Mussey E: Cancer metastatic to the ovary: factors influencing survival. Obstet Gynecol 1975;45:391-6.

6 Horie K, Konishi I, Fuji S, Kosaza H, Noda Y, Okamura H, Mori T: A clinical study of metastatic ovarian tumors. Adv Obstet Gynecol 1986;38:435.

7 Gagnon Y, Tetu B: Ovarian metastases of breast carcinoma. A clinicopathologic study of 59 cases. Cancer 1989;15:892-8.
8 Yada-Hashimoto N, Yamamoto T, Kamiura S, Seino H, Ohira H, Sawai K, Kimura T, Saji F: Metastatic ovarian tumors: a review of 64 cases. Gynecol Oncol 2003;89:314-7.

9 Le Bouedec G, de Latour M, Levrel O, Dauplat J: Krukenberg tumors of breast origin. 10 cases. Presse Med 1997;29;26:454-7.

10 Perrotin F, Marret H, Bouquin R, Fisher-Perrotin $\mathrm{N}$, Lansac J, Body G: Incidence, diagnosis and prognosis of ovarian metastasis in breast cancer. Gynecol Obstet Fertil 2001;29:308-15. 